\title{
RANCANGAN SISTEM INFORMASI DALAM PENGEMBANGAN MODEL TRACER STUDY DI UNIVERSITAS DHARMAWANGSA
}

\author{
Jovi Antares ${ }^{{ }^{*}}$, Zelvi Gustiana ${ }^{1}$, Ibnu Rusydi ${ }^{2}$ \\ ${ }^{1}$ Teknologi Informasi, Universitas Dharmawangsa \\ ${ }^{2}$ Rekayasa Perangkat Lunak, Universitas Dharmawangsa \\ email: "joviantares@dharmawangsa.ac.id
}

\begin{abstract}
The tracer study is a method of alumni tracker carried out by state universities and private universities .A function of the tracer study is a source of information and to know the presence of alumni and provides information and an evaluation for stakeholders to know the quality of a college education. The implementation of the tracer study at the university of dharmawangsa is still done manually using google form that is facility from google, so the implementation in collecting the inefficient .Researchers to develop a web based information system for the purpose of completing deficiencies in the implementation of the tracer study. The goal is to ease the tracer study for stakeholders to an efficiently..
\end{abstract}

Keywords: alumni; tracer; tracer study; stakeholders; web

\begin{abstract}
Abstrak: Tracer study adalah suatu metode pelacakkan alumni yang dilaksanakan oleh perguruan tinggi negeri dan perguruan tinggi swasta. Fungsi dari tracer study adalah sebagai sumber informasi dan untuk mengetahui keberadaan dari alumni serta dapat menyediakan informasi dan bahan evaluasi bagi stakeholders untuk mengetahui kualitas pendidikan perguruan tinggi. Pelaksanaan tracer study di Universitas Dharmawangsa masih dilakukan secara manual menggunakan google form yang merupakan fasilitas dari google, sehingga pelaksanaannya dalam menghimpun data kurang efisien. Peneliti bermaksud membangun suatu sistem informasi berbasis web dengan tujuan untuk menyelesaikan kekurangan dalam pelaksanaan tracer study. Tujuannya adalah untuk memudahkan bagi stakeholders untuk melaksanakaan tracer study secara efisien.
\end{abstract}

Kata kunci: alumni; pelacakan; tracer study; web

\section{PENDAHULUAN}

Perguruan tinggi merupakan pihak sebagai penyelenggara pendidikan tinggi yang memiliki andil besar dalam mencerdaskan anak bangsa, terutama dalam menghasilkan lulusan-lulusan terbaik dan berkualitas yang siap kerja di masyarakat [1]. Perguruan tinggi harus melakukan penelusuran terhadap lulusannya yang sudah menyebar [2]. Alumni merupakan produk yang dihasilkan oleh institusi pendidikan yang menggambarkan bagaimana tercapainya visi dan misi dari institusi asal alumni [3]. Institusi perlu melakukan pelacakan data untuk lulusannya, data ini bisa digunakan dan diperlukan dalam berbagai kebutuhan, trac- 
er study bisa menjadi media alternatif yang efektif untuk mendapatkan data lulusan [4].

Tracer Study merupakan suatu metode pelacakkan atau survey alumni yang dilaksanakan oleh Perguruan Tinggi Negeri maupun Perguruan Tinggi Swasta [5]. Tujuan dari tracer study tersebut digunakan untuk sebagai sumber informasi dan untuk mengetahui penyerapan, proses, dan posisi lulusan dalam dunia kerja serta membantu program pemerintah dalam memetakan kebutuhan dunia kerja dengan kompetensi yang diperoleh dari perguruan tinggi [6].

Disamping itu, tracer study dapat menyediakan informasi untuk kepentingan bahan evaluasi bagi perguruan tinggi dan selanjutnya menjadi acuan untuk meningkatkan serta menyempurnakan kualitas pendidikan perguruan tinggi [7]. Tracer study menyediakan informasi yang berharga bagi masyarakat dan pemangku kepentingan (stakeholders) untuk mengetahui seberapa besar kompetensi yang dimiliki oleh perguruan tinggi dan tracer study dapat dijadikan sebagai bahan akreditas perguruan tinggi [8].

Universitas Dharmawangsa menunjuk lembaga yang berwenang dalam pelaksanaan tracer study ini adalah Lembaga Pusat Karir Universitas Dharmawangsa. Lembaga ini berdiri berdasarkan Surat Keputusan Rektor Nomor R.020.10.032018-298 tahun 2019 tertanggal 14 Maret 2018 tentang Pengurus Pusat Karir Universitas Dharmawangsa. Salah satu fungsi Lembaga Pusat Karir Universitas Dharmawangsa adalah melaksanakan kegiatan pelacakkan lulusan (tracer study) Universitas Dharmawangsa. Pelaksanaan tracer study yang dilakukan oleh Lembaga Pusat Karir berkerjasama dengan 6 Fakultas di lingkungan Universitas Dharmawangsa yaitu, Fakultas Agama Islam, Fakultas
Ekonomi dan Bisnis, Fakultas Ilmu Sosial dan Ilmu Politik, Fakultas Perikanan, Fakultas Hukum, dan Fakultas Teknik dan Ilmu Komputer.

Namun dalam implementasinya, tracer study memiliki kendala atau hambatan dalam melacak, survey, dan follow up keberadaan alumni. Faktor hambatan dalam pelaksanaan tracer study yaitu sistem pelaksanaannya masih sangat sederhana [9]. Cara yang digunakan selama ini salah satunya adalah menyebarkan kuisuoner menggunakan formulir kertas dan penyebaran menggunakan link google form serta belum adanya sistem yang digunakan dalam tracer study tersebut [10]. Hal ini dapat menimbulkan masalah dalam pelacakkan alumni perguruan tinggi karena keterbatasan yang ada. Keterbatasan ini yang dapat mengakibatkan tidak tercapainya target dalam pelaksanaan tracer study di Universitas Dharmawangsa. Kendala lain yang ditimbulkan oleh sistem tracer study yang masih sederhana adalah proses pengumpulan data pada tracer study masih menggunakan sistem manual. Hal ini menimbulkan kendala lain seperti sulitnya proses pengumpulan data serta membutuhkan waktu yang lama, terjadinya data ganda (redudansi data), dan proses pelaporan atau output dilaksanakan secara manual.

Sejak tahun 2018, jumlah alumni Universitas Dharmawangsa yang sudah terdaftar pada PD-Dikti sebanyak 3.875 alumni. Namun, feedback atau umpan balik yang diberikan adalah sebanyak 601 alumni (15.5\%). Dengan adanya keterbatasan sistem tracer study serta proses yang masih sederhana, pelaksanaan tracer study jauh dari target yang diharapkan oleh pihak perguruan tinggi sehingga pihak perguruan tinggi, program studi, dan pemangku kepentingan (stakeholders) masih kesulitan dalam 
menilai dan mengevaluasi mutu kompetensi yang ada.

\section{METODE}

Metode pengembangan sistem pada penelitian adalah Model Waterfall [11]. Model Waterfall dicetuskan sebagai contoh metodologi pengembangan perangkat lunak pada tahun 1970 [12]. Tahap pada metode waterfall yaitu :

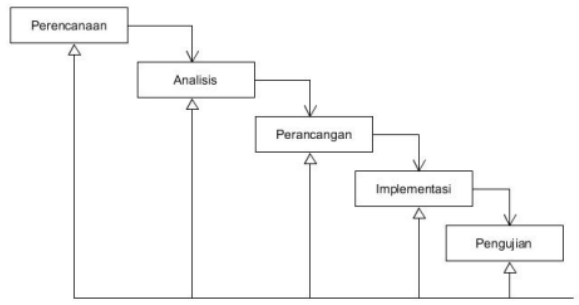

Gambar 1. Tahapan pengembangan pada metode waterfall

\section{Perencanaan}

Tahap ini memiliki tujuan untuk mengarahkan perancangan agar memiliki kecocokan dengan sistem yang akan dibangun, kemudian memberikan batasan terhadap apa yang diizinkan dilakukan atau yang tidak diizinkan untuk dilakukan dalam pembuatan sistem.

\section{Analisis}

Tahap analisis memiliki tujuan secara keseluruhan mendapatkan pemahaman mengenai testing system informasi yang dikembangkan menurut masukan dari user. Tahap ini bertujuan menentukan solusi mengenai sistem yang akan dibuat. Analisis ini memiliki hasil yaitu pemahaman terhadap sistem secara keseluruhan sebagai persiapan untuk tahan ke berikutnya yaitu tahap perancangan atau desain.

\section{Perancangan}

Tahapan ini memiliki tujuan untuk menentukan bentuk sistem arsitektur berdasarkan standar dan batasan teknologi, kemudia pada implementasi sistem dibuat abstraksi yang tak terlihat. Ana- lisis ini memiliki hasil berupa sebuah desain website yang responsif.

\section{Implementasi}

Sebuah sistem siap dan dapat implementasikan setelah melalui tahapan diatas. Pada tahapan implementasi ini, terdapat beberapa pekerjaan yang dilakukan diantaranya mengimplementasikan desain yang dibuat pada sebuah komponen source code, script dan tabel, selanjutnya penyempurnaan arsitektur dan pengujian sistem.

\section{Pengujian}

Setelah melakukan serangkaian pekerjaan pada implementasi, selanjutnya terdapat sebuah pengujian atau testing. Prosedur Blackbox dilakukan pada pengujian ini [13].

\section{HASIL DAN PEMBAHASAN}

\section{Perancangan UML}

Tahap ini berisikan hasil analisa, hasil perancangan dan pengimplemetasian uji sistem. Pertama, tahap awal yaitu hasil analisa yang dituangkan dalam bentuk UML (Unified model Language) yang diterapkan pada sistem aplikasi tracer study yang sedang dikerjakan pada penelitian.

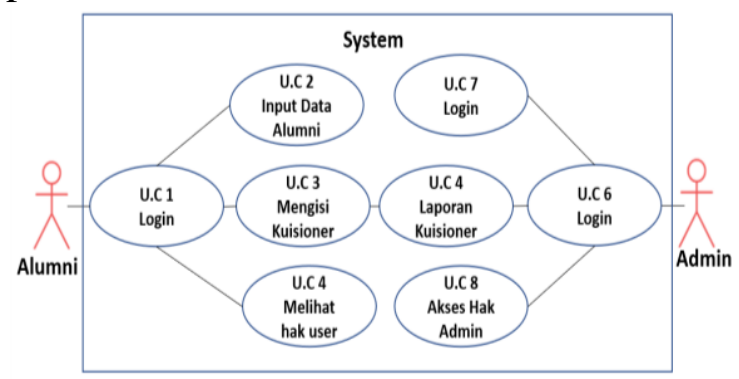

Gambar 2. Use Case Diagram

Use case diagram pada gambar diatas menjelaskan tentang hasil analisa dari sistem aplikasi tracer study yang dibuat dalam penelitian ini. Use case dijelaskan pada tabel 1: 
DOI: https://doi.org/10.33330/jurteksi.v7i2.1002

Available online at http://jurnal.stmikroyal.ac.id/index.php/jurteksi

Tabel 1. Use case diagram

\begin{tabular}{|c|c|c|}
\hline No & Use Case & Ket \\
\hline $\begin{array}{c}\text { U.C } \\
1\end{array}$ & Login & $\begin{array}{l}\text { Alumni melakukan } \\
\text { login untuk masuk ke } \\
\text { sistem, tapi sebelum itu } \\
\text { Alumni harus } \\
\text { melakukan registrasi }\end{array}$ \\
\hline $\begin{array}{c}\text { U.C } \\
2\end{array}$ & $\begin{array}{l}\text { Input } \\
\text { Data } \\
\text { Alumni }\end{array}$ & $\begin{array}{l}\text { Alumni harus mengisi } \\
\text { data sebelum mengis } \\
\text { kuisioner }\end{array}$ \\
\hline $\begin{array}{l}\text { U.C } \\
3\end{array}$ & $\begin{array}{l}\text { Mengisi } \\
\text { Kuisioner }\end{array}$ & $\begin{array}{lr}\text { Alumni } & \text { mengis } \\
\text { Kuisioner } & \text { yang } \\
\text { disediakan } & \end{array}$ \\
\hline $\begin{array}{c}\text { U.C } \\
4\end{array}$ & $\begin{array}{l}\text { Laporan } \\
\text { Kuisioner }\end{array}$ & $\begin{array}{l}\text { Laporan dari kuisioner } \\
\text { yang hanya diakses } \\
\text { oleh admin }\end{array}$ \\
\hline $\begin{array}{c}\text { U.C } \\
5\end{array}$ & Hak User & $\begin{array}{l}\text { Alumni dapat melihat } \\
\text { hak akses yang } \\
\text { diberikan kepadanya }\end{array}$ \\
\hline $\begin{array}{c}\text { U.C } \\
6\end{array}$ & Login & $\begin{array}{l}\text { Admin melakukan } \\
\text { login untuk masuk ke } \\
\text { sistem }\end{array}$ \\
\hline $\begin{array}{c}\text { U.C } \\
7\end{array}$ & $\begin{array}{l}\text { Pengelola } \\
\text { an } \\
\text { Kuisioner }\end{array}$ & $\begin{array}{lr}\text { Admin } & \text { membuat } \\
\text { Kuisioner } & \text { untuk } \\
\text { Alumni } & \end{array}$ \\
\hline $\begin{array}{c}\text { U.C } \\
8\end{array}$ & $\begin{array}{l}\text { Hak } \\
\text { Akses } \\
\text { Admin } \\
\end{array}$ & $\begin{array}{l}\text { Admin dapat melihat } \\
\text { semua yang menjadi } \\
\text { hak aksesnya }\end{array}$ \\
\hline
\end{tabular}

Setelah dilakukan penganalisaan dan mendapatkan hasil terhadap sistem informasi tracer study yang dikerjakan, maka dilakukan pembuatan perancangan sistem untuk mengetahui alur aktivitas pada setiap sistem.

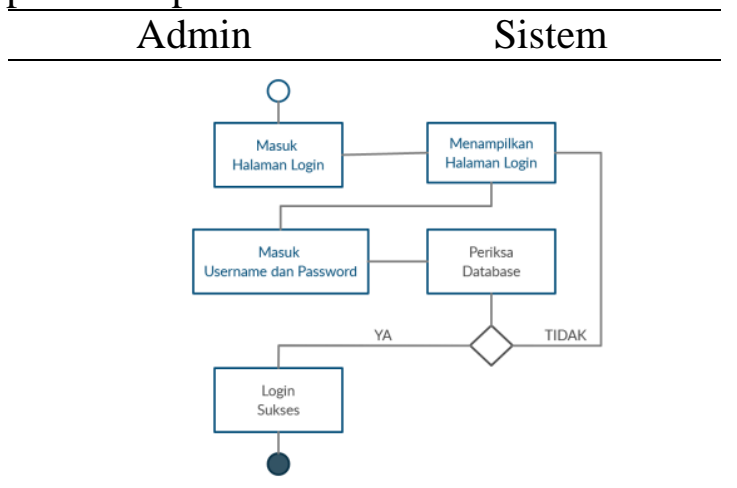

Gambar 3. Activity diagram login admin

Diagram activity login yang diperlihatkan pada gambar 3 adalah kegiatan yang dilakukan oleh admin tracer study. Diagram itu terdiri atas aktivitas yang menampilkan halaman login yang dengan mengisikan username dan password, halaman ini hanya bisa diakses oleh admin.

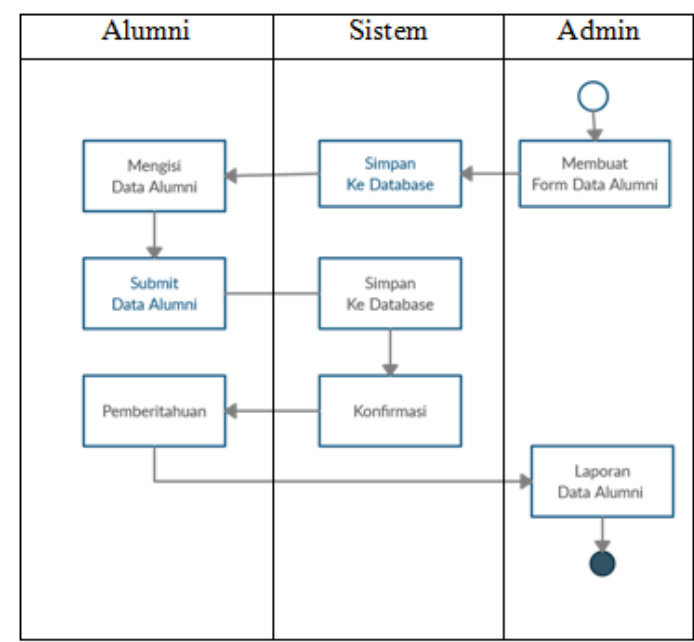

Gambar 4. Activity form input alumni

Pada Diagram aktiviti ini form data alumni dibuat oleh admin, kemudian disimpan ke dalam database sebelum diberikan kepada alumni untuk diisi.

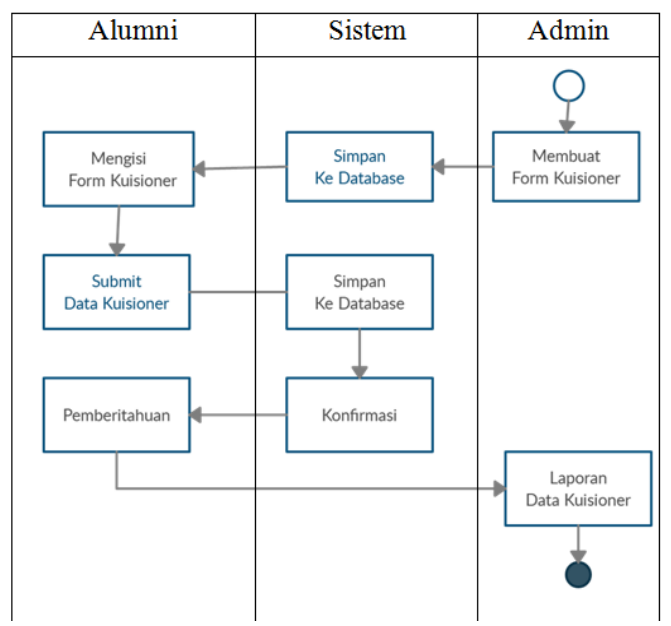

Gambar 5. Activity form Data Kuisioner

Sama seperti Diagram activity pada form input data alumni, form data kuisioner awalnya dibuat oleh admin sebelum disimpan ke dalam database, kemudian alumni yang sudah login dapat melakukan mengisian terhadap kuisioner dengan menjawab pertanyaan-pertanyaan 
yang telah disediakan. Kemudian data disimpan kembali ke database, dan admin dapat melihat jawaban-jawaban dari kuisioner berbentuk laporan.

\section{Rancangan ERD (Entity Relationship Diagram)}

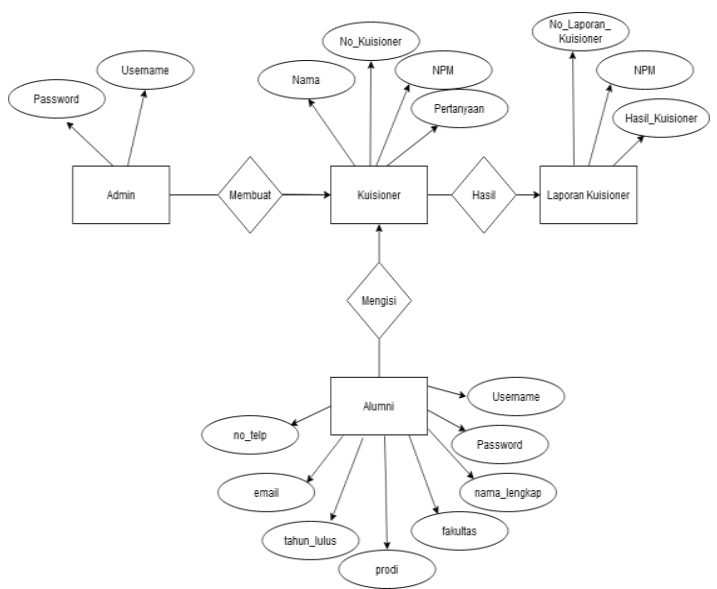

Gambar 6. Entity relationship diagram

Pada Gambar 6 dapat dilihat hubungan atau relasi dari tabel-tabel yang digunakan dalam sistem informasi tracer study yang dikerjakan. Alumni dapat mengisi kuisioner setelah melakukan login dan registrasi, dan Admin dapat mengelola semua yang ada di dalam sistem termasuk laporan dari kuisioner yang diisi oleh alumni.

\section{Implementasi Website Tracer Study}

Setelah melakukan tahap analisis dan perancangan sistem informasi, maka yang dilakukan selanjutnya adalah tahap implementasi. Penulis membuat sebuah program pada tahap ini dengan hasil sebagai berikut :

a. Halaman utama Website

Halaman ini merupakan tampilan awal saat kita mengunjungi website. Halaman ini berisi menu utama berupa Home, Alumni, Admin Login dan Contact Us

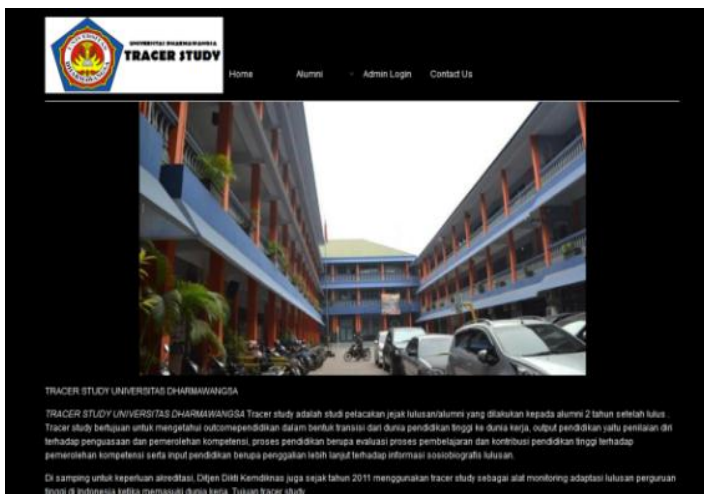

Gambar 7. Halaman utama website

b. Halaman Login

Halaman ini merupakan akses yang hanya dilakukan oleh admin dan alumni. Halaman login bertujuan konfirmasi administrator melalui username dan password sebagai bentuk penjagaan keamanan data. Bagian-bagian dari halaman login antara lain : Username, adalah nama user atau dalam hal ini adalah admin. Password, adalah gabungan karakter berupa huruf dan angka.

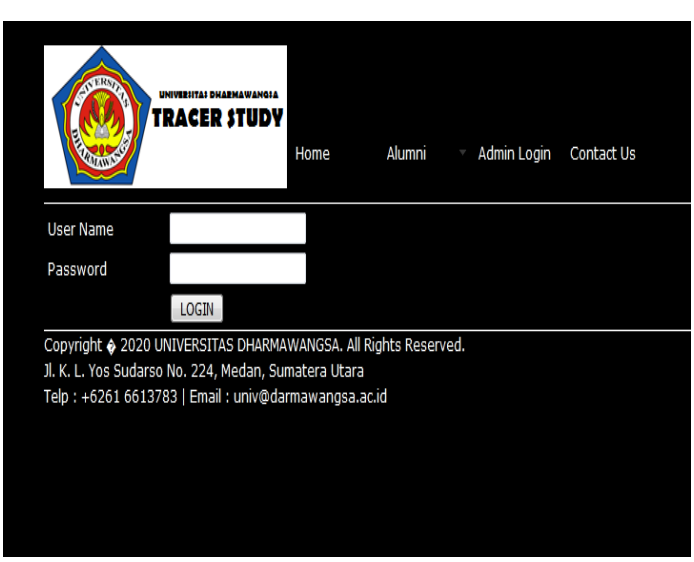

Gambar 8. Halaman Login Admin

c. Halaman Form Input Registrasi Alumni

Halaman ini berisikan form registrasi yang harus diisi oleh alumni sebelum masuk ke dalam sistem untuk mengisi kuisioner yang telah disediakan. 
Available online at http://jurnal.stmikroyal.ac.id/index.php/jurteksi

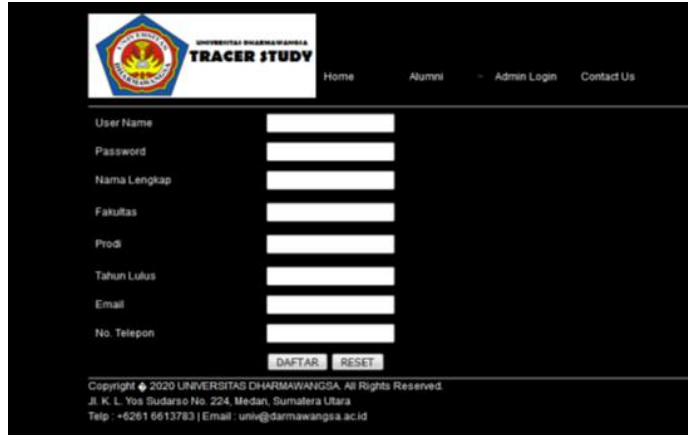

Gambar 9. Halaman Registrasi Alumni

\section{d. Form Kuisoner Utama}

Form kuisoner utama merupakan pokok dari sistem informasi tracer study Universitas Dharmawangsa. Pada halaman ini alumni yang telah terdaftar pada form registrasi, selanjutnya dapat mengisi tracer study yang berbentuk kuisoner yang telah ditetapkan. Bentuk laman dalam form kuisoner utama tertuang pada gambar 10 .

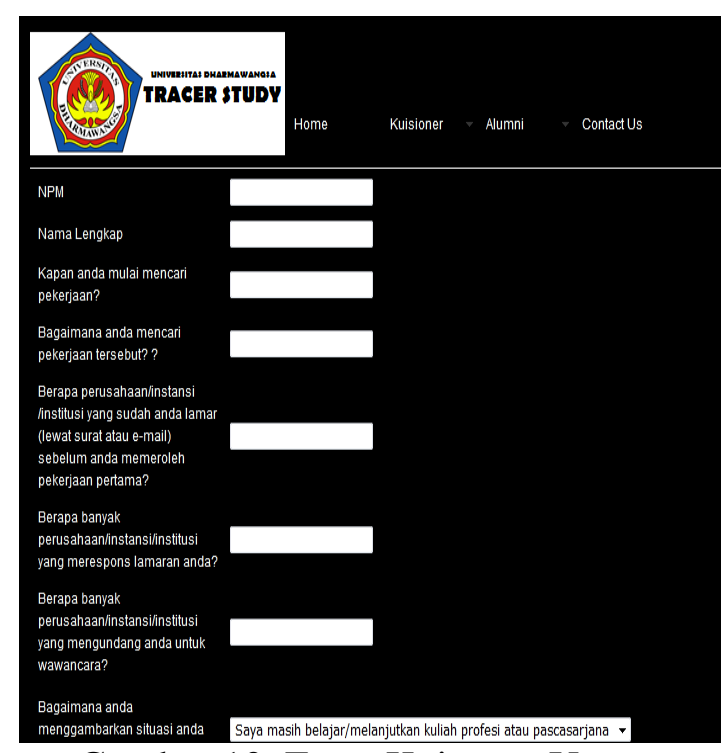

Gambar 10. Form Kuisoner Utama

e. Halaman Laporan

Halaman laporan merupakan ouput dari sistem informasi tracer study yang telah dibangun. Laporan tersebut berupa tabel-tabel yang telah disusun berdasarkan bentuk rancangan yang telah dibangun. Laporan dari tracer study terdiri dari 2 jenis yaitu, laporan data alumni yang merupakan informasi yang berisi identitas dari alumni yang telah mengisi tracer study. Laporan data alumni dapat dilihat pada gambar 11 .

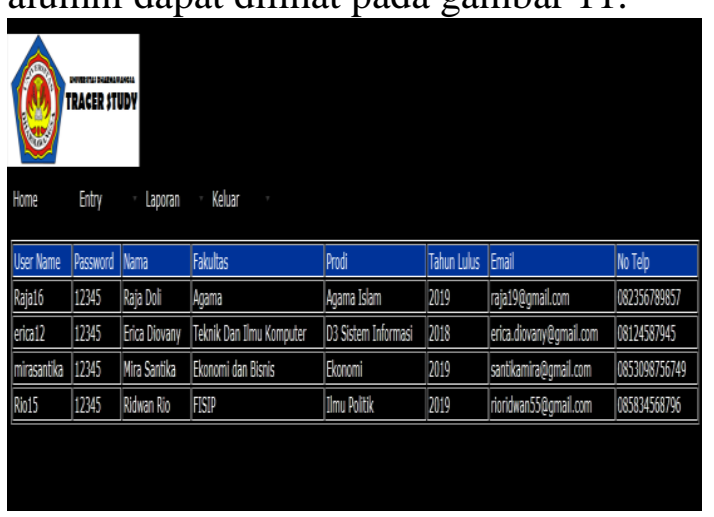

Gambar 11. Laporan Data Alumni

Selanjutnya terdapat laporan kuisoner yang merupakan informasi terhadap kuisoner yang telah diisi oleh alumni. Laporan kuisoner dapat dilihat pada gambar 12 .

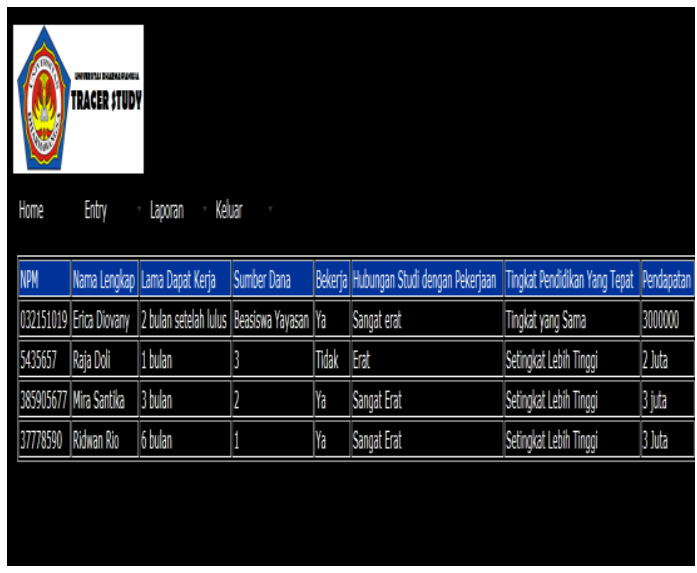

Gambar 12. Laporan Kuisoner

\section{Hasil Pengujian}

Pengujian terhadap website yang telah dikerjakan dengan menggunakan metode blackbox, yaitu pengujian kebutuhan fungsi terhadap setiap menu suatu program, kemudian diperiksa dan diproses sehingga menghasilkan keluaran atau output yang diharapkan dan sesuai 
Available online at http://jurnal.stmikroyal.ac.id/index.php/jurteksi

dengan kebutuhan sistem. Salah satu percobaan adalah Pengujian blackbox pada form login.

Skenario pengujian dengan memasukkan username dan password yang salah lalu klik login. Hasil dari pengujian aplikasi tracer study adalah pengguna/alumni dapat dengan mudah melakukan input data serta memudahkan bagi admin Universitas Dharmawangsa dalam menghimpun dan mengumpulkan data. Pengolahan data pada aplikasi tracer study dijalankan secara otomatis dikarenakan penggunaan sistem informasi berbasis web dan penggunaan database.

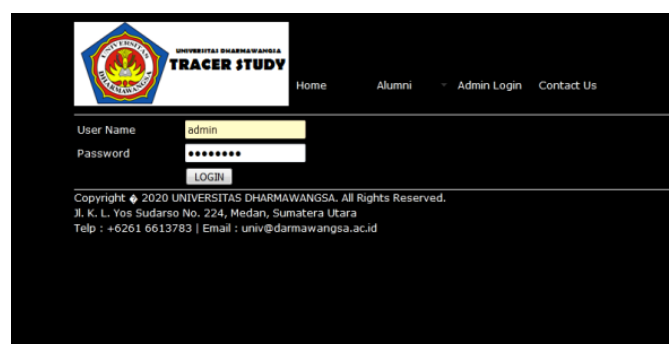

Gambar 13. Test Case Login

\section{Prosedur Kerja Sistem}

Prosedur sistem informasi tracer study Universitas Dharmawangsa ini sangat membantu memudahkan admin dalam bagian tracer study, terutama masalah pengisian tracer study. Berikut ini prosedur sistem informasi tracer study

1. Sistem hanya dapat diakses penuh oleh admin, serta alumni dapat masuk ke dalam setalah mengisi form registrasi.

2. Admin dan alumni masuk ke dalam sistem menggunakan username dan password.

3. Alumni mengisi data diri dan kuisoner mengenai tracer study.

4. Admin dapat melihat laporan data alumni dan kuisoner tracer study alumni.

5. Sistem informasi ini terkoneksi ke database sehingga data yang dimasukkan akan disimpan secacara otomatis

\section{SIMPULAN}

Dari hasil tahap analisis dan perancangan sistem informasi, maka yang dilakukan selanjutnya adalah tahap implementasi website tracer study yang dibuat. Setelah melakukan pengujian blackbox, Website tracer study Universitas Dharmawangsa dapat membantu dalam pelacakan alumni dengan maksimal dan efisien. Pada penelitian selanjutnya, tracer study ini dapat dipadukan dengan metode data mining seperti Naïve Bayes, K-Means, Case Based Reasoning (BCR) Dempster Shafer dan sebagainya yang dapat digunakan sebagai alat pengukuran kinerja dan prediksi terhadap lulusan.

\section{DAFTAR PUSTAKA}

[1] Rasyid, Saifuddin A. 2018. "Tracer Study Tentang Link and Match Alumni S1 Ilmu Perpustakaan Fah UIN Ar-Raniry Dan Dunia Kerja Di Wilayah Pantai Barat Selatan Aceh." 10(1):66-80.

[2] Fajaryati, Nuryake, Sigit Pambudi, Priyanto Priyanto, Totok Sukardiyono, Athika Dwi Wiji Utami, and Bonita Destiana. 2015. "Studi Penelusuran (Tracer Study) Terhadap Alumni Program Studi Pendidikan Teknik Informatika Jurusan Pendidikan Teknik Elektronika Fakultas Teknik Universitas Negeri Yogyakarta." Elinvo (Electronics, Informatics, 
and Vocational Education) 1(1):4445.

doi: 10.21831/elinvo.v1i1.10878.

[3] Juwita, Mega Isma, Satrio Agung Wicaksono, and Nanang Yudi Setiawan. 2019. "Pengembangan Sistem Informasi Tracer Study Alumni Berbasis Web Menggunakan Metode RUP ( Studi Kasus : SMA Suluh Jakarta Selatan )." Jurnal Pengembangan Tenknologi Informasi Dan Ilmu Komputer 3(6):5703-10.

[4] Akbar, Rizaldi, and Mukhtar Mukhtar. 2020. "Perancangan ETracer Study Berbasis Sistem Cerdas." Jurnal Sisfokom (Sistem Informasi Dan Komputer) 9(1):812. doi: 10.32736/sisfokom.v9i1.631.

[5] Rizka, Muhammad, Amri Amri, Hendrawaty Hendrawaty, and Mahdi Mahdi. 2018. "Analisis Dan Perancangan Sistem Informasi Tracer Study Berbasis WEB." Jurnal Infomedia 3(2):69-73. doi: 10.30811/jim.v3i2.716.

[6] Haerudin, Heri, Ari Syaripudin, Dimas Abisono Punkastyo, Farida Nurlaila, and Joko Riyanto. 2021. "Sistem Tracer Study Dan Monitoring Alumni Universitas Pamulang." 5(4):498-505.

[7] Rusli, Ahmad, and Ilyas. 2020. "Sistem Informasi Tracer Study Alumni Universitas Islam Indragiri Berbasis Web." Jurnal Perangkat Lunak 2(1):41-50. doi: 10.32520/jupel.v2i1.1083.

[8] Nuari, A. 2020. "Sistem Informasi Tracer Study Berbasis Web." 9(2):1-7.

[9] Muhammad Arifin, and Syaiful Muzid. 2018. "Analisa Tracer Study Pada Universitas XYZ." Jurnal Disprotek 9(2):69-73. doi: 10.34001/jdpt.v9i2.799.

[10] Chrisnanto, Herawan, and Info Artikel. 2018. "Journal of Sport Coaching and Physical Education." Journal of Sport Coaching and Physical Education 3(1):33-41.

[11] Gustiana, Zelvi. 2020. "Perancangan Sistem Informasi Data Karyawan Pt . Socfin Indonesia Medan.” 1(2).

[12] Satria Welnof, Universitas Dharmawangsa. 2020. "Jaringan Syaraf Tiruan Backpropagation Untuk Peramalan Penjualan Produk ( Studi Kasus Di Metro Electronic Dan Furniture )." 1(1):14-19.

[13] Antares, Jovi. 2020. "Rancangan Sistem Informasi Kependudukan Berbasis Web Di.”1(2). 